\title{
OVER A MILLION STUDENT TENANTS IN POLAND. ANALYSIS OF PREFERENCES
}

\author{
Alina Źróbek-Różańska, PhD \\ Faculty of Economic Sciences \\ University of Warmia and Mazury in Olsztyn \\ e-mail:alina.zrobek@uwm.edu.pl
}

\section{Lucyna Szulc}

\begin{abstract}
Students as property tenants are an underestimated and understudied aspect of the market. To date, there has been a widely held opinion that student decisions in the property market and their scope are mostly limited to the area of academic centres. It is estimated that, in Poland, over a million students enter into tenancy agreements annually, most of which are in the private property market. Such wide demand is directed at selected, diverse locations and dwellings of particular characteristics, satisfying the preferences of young people at a specific moment of their lives (the so-called "emerging adults"). The present article aims to present answers to the question of what motivates students who undertake transactions in the property market. Information on the characteristics of the sought after properties was obtained by way of surveys, leading to the generation of a set of the most important features determining the attractiveness of properties from the point of view of the analyzed population. The phenomenon of the popularity of particular locations (urban estates) has also been examined in detail.
\end{abstract}

Key words: rental market, residential property, student.

JEL Classification: D10, R21, R39.

Citation: Źróbek-Różańska A., Szulc L., 2018, Over a Million Student Tenants in Poland. Analysis of Preferences, Real Estate Management and Valuation, vol. 26, no. 2, pp. 104-113.

DOI: $10.2478 /$ remav-2018-0020

\section{Introduction}

The property market is a complex system of dynamic processes and rules regulating the changes in property ownership and its manner of use. It is also a contractual space filled with economic, technical, physical and legal determinants, in which owners of various property rights negotiate the terms and conditions of the transactions with the persons acquiring these rights. Each side of the transaction, prior to proper negotiations, must make several decisions concerning their own expectations and capabilities. The matter of decision making by property market participants has been subject to numerous studies (e.g. MCFADDEN 1997; DE PALMA et al. 2005; TROJANEK 2013; BRZEZICKA, WIŚNIEWSKI 2014; KUCHARSKA-STASIAK 2016; ŹRÓBEK-RÓŻAŃSKA et al. 2016). What follows from the analysis of the demand side of the property market is the observation that the basic decision made by the potential buyers is the choice of the property right. The subject of the transaction can be either rights in rem (also restricted), which include proprietary rights, or the right of obligation, which includes rental. The choice of the property right depends largely on its availability in the market, the kind of the transaction subject (e.g. if it is an agricultural estate, commercial estate, or a dwelling) and the factors which characterize the purchaser (e.g. their disposable income, mobility and individual preferences). This paper deals with the considerations given to the choices made by a specific group of participants in the residential property market. For such properties, the choice comes down to either renting or acquiring full property rights. The final decision is a function of many factors, which 
include both the availability of specific kinds of property rights and the perception of the advantages and disadvantages by the purchasers. In addition, the decision is determined by the characteristics of the purchasers themselves, such as: their age, stage of life, preference for ownership over rental and the manner of money management. An interesting group of purchasers in the property market are the so-called "emerging adults," described by, among others, J.J. ARNETT (2000). These are persons 18-25 years of age, experimenting with new social roles, who are flexible, undecided about the future, making their first independent decisions concerning their place of residence (moving away from their parents), but who often remain financially dependent (they do not earn income, thus their expenses are part of the general expenses incurred by the household of their parents or caretakers). This description also applies to students of higher education. This is a numerous group - the number of students worldwide is estimated at 100 million $^{1}, 20$ million of which are in the European Union ${ }^{2}$ and nearly 1.5 million in Poland ${ }^{3}$. Due to the location of the main academic centers in the largest cities, the majority of the student population come from other cities and satisfy their dwelling needs by concluding transactions (formal and informal) in the local residential property market. At the same time, these persons usually do not register in the new place of residence and, from the formal point of view, remain inhabitants of their home cities. The objective of this paper was to find an answer to the question: what motivates students who enter into transactions in the local property market? To meet this objective, students' preferences as to their dwellings needs were examined on a group of students enrolled in tertiary institutions in the city of Olsztyn.

\section{Literature review}

A residential property is characterized by two seemingly opposite features; on one hand, it is an essential good, ensuring the satisfaction of the physiological need for shelter; on the other, it satisfies needs of a higher rank, such as comfort and prestige. For that reason, it is an expensive good, not affordable by everyone (NYKIEL 2012). It follows that, in addition to transactions of ownership transfer, the rental market is also growing. The number of people residing in rented accommodation is estimated to be 1.2 billion (GILBERT 2016). Generally, the rental market develops along with migration from the country to the city, though this process is by no means homogenous on a worldwide scale; for instance, in the case of Austria, 25\% of households occupied rented accommodation (HULSE et al. 2006), 35\% in Great Britain (JADACH-SEPIOŁO 2014), 58\% in Germany and 66\% in Switzerland (GILBERT 2016). In former socialist countries, the share of rented accommodation is relatively low, e.g. in Bulgaria, Estonia, Hungary, Kyrgyzstan, Romania, or Slovenia it was less than 20\% (GROVER et al. 2002). Similar values were noted for Spain, Greece and Ireland (CZERNIAK, RUBASZEK 2016). In Poland, that number is even lower - in 2016 merely 5.5\% of households lived in rented accommodation, paying the market rent or lower (WARUNKI ŻYCIA ...2014).

CZERNIAK and RUBASZEK (2016), referring to research carried out by ANDREWS and CALDERA SANCHEZ (2011), CUERPO et al. (2014) and de BOER and BITETTI (2014), emphasize that the proportion between the apartments which the dwellers enjoy property rights to and rented accommodation depends largely on economic (property prices and the income of the population) as well as demographic and institutional factors, in accordance with the housing policy run by a particular country, and finally, the higher value ascribed to the proprietary right. They also observed that the willingness to rent decreases with age and increases with mobility (immigrants have lower income and restricted capacity to inherit property). In turn, the propensity for acquiring property rights increases with income; this, however, has to be an increase in stable income, as the growth of the current income has a relatively low influence on the demand for property (FRIEDMAN 1957; LEE 1968; CHEN, JIN 2014). At the same time, the housing policy determines the decisions on the property market, as in some countries (like China or Cuba), it can take the form of private rent prohibition, (GILBERT 2016) or promote ownership by convincing the citizens that the property owners are in a significantly better life situation than tenants (WATSON, WEBB 2009).

\footnotetext{
1 Sprawozdanie na temat strategii Komisji Europejskiej „Europejskie szkolnictwo wyższe na świecie” (www.senta.gov.pl, retrieved 25.04.208).

${ }^{2}$ Statistical data on higher education (http:/ / ec.europa.eu, retrieved 25.04.2018).

${ }_{3}^{3}$ Higher education in the academic year 2016/2017, GUS preliminary data (http://stat.gov.pl, retrieved 20.04.2018).
} 
The decision on the kind of property right (in this case ownership or rent) calls for a consideration of pros and cons of each option. One argument in favor of the ownership is that one's own property constitutes a safe capital investment and financial security devoid of the risk of a sudden hike in the rent or fear of eviction, which is important especially to people nearing their retirement age (VENTI, WISE 2004). Additionally, the ownership of property has formed positive associations with freedom and independence, as it provides the free reign to shape the dwelling space according to one's own needs and abilities, and the right to the property can be passed on to heirs (KURZ 2004). As far as the drawbacks of property ownership are concerned, it is a very capital intensive solution, which often means the necessity of taking out a long term mortgage; another issue is its low liquidity, which hinders the mobility of the owners. On the other hand, one shortcoming of property rental is uncertainty, as the amount of the rent depends on the owner, and may be raised to an unacceptable level. The rental agreement can also be terminated at short notice for several reasons, including the sale of the property. However, the advantage of the rental is its relatively lower capital intensity and the possibility of moving the location at any time. These characteristics are particularly important to people on low income and those who have just moved to a given city and are not certain yet where they want to live on a permanent basis. The people who have come to the city to study at college, who do not earn a steady income, and who do not have definite plans to stay in the city upon completion of higher education, are more likely to seek rented accommodation.

The housing policy in many countries tends to promote the rental market as an alternative to property ownership. From the macroeconomic perspective, the development of the rental market should bring numerous benefits as it provides accommodation to people who cannot afford to purchase property and has a positive influence on the increase in mobility. In Poland, the development of the rental market is encouraged through the commercial Rented Accommodation Fund or the Apartment Plus programme, which envisages the construction of affordable rental apartments, which the occupants may eventually purchase for full ownership. At the moment, most rented apartments are owned by natural persons (so-called "mom and pop owners," AUGUST and WAKS 2018), who treat the rent as an additional source of income from a single apartment (JADACHSEPIOŁO 2014). This makes research of the rental market more difficult, as a large number of the transactions are never registered and the owners charge rent without duly informing the Tax Office (KUCHARSKA-STASIAK 2016).

Due to the lack of reliable data available through the institutions, the examination of the rental market is supported by own research conducted directly among the tenants. It must be stressed that students of higher education constitute a large, multi-million group (often informal) of tenants. As Russo and Tatjer (2007) noted, students are an important and understudied group which shapes the structure of whole cities. Until recently, students were usually perceived as university campus residents and most attention was paid to the academic centres themselves as important elements of urban architecture (HALL 1997). The impact of students on areas beyond the campus was studied by SMITH (2009), who popularized the term "studentification of urban space." Currently, students are more frequently classified as the third urban population (the first are the residents of the city, the second are the suburban population) and treated as temporary, mobile consumers, who use the urban facilities and bring about several transformations (BAJERSKI 2015). This studentification is also evident in the property market - in cities where academic centres are located, the rental accommodation becomes more expensive and the share of apartments occupied by the owners goes down (ADAMS et al. 2009). This process is also not without an influence on the residential infrastructure - it can improve when new estates are built with rental in mind, or when old buildings are renovated and adapted to the students' needs, but it can also deteriorate, e.g. when the temporary residents do not take sufficient care of the shared infrastructure in the estates inhabited by students (BAJERSKI 2015). Students from other countries and cultures also have an increasing impact on the property market. Supported by substantial subsidies, they are seen as "exotic, rich, materialistic creators of cosmopolitism (COLLINS 2010)."

\section{Data and Methods}

To meet the assumed objective, i.e. to find the answer to the question "What motivates students who choose particular apartments?" we embarked on the following stages of research:

1) considering the specific nature of the rental market in the world and in Poland, 
2) reviewing the characteristics of the transactions concluded by students in the local property markets.

The first stage consisted of a review of literature, reports and statistical data. In the second stage, we made use of research results of other scientists into the attitudes of students in the property markets of Great Britain, Australia and Poland as well as our own research results of the attitudes of students in Olsztyn.

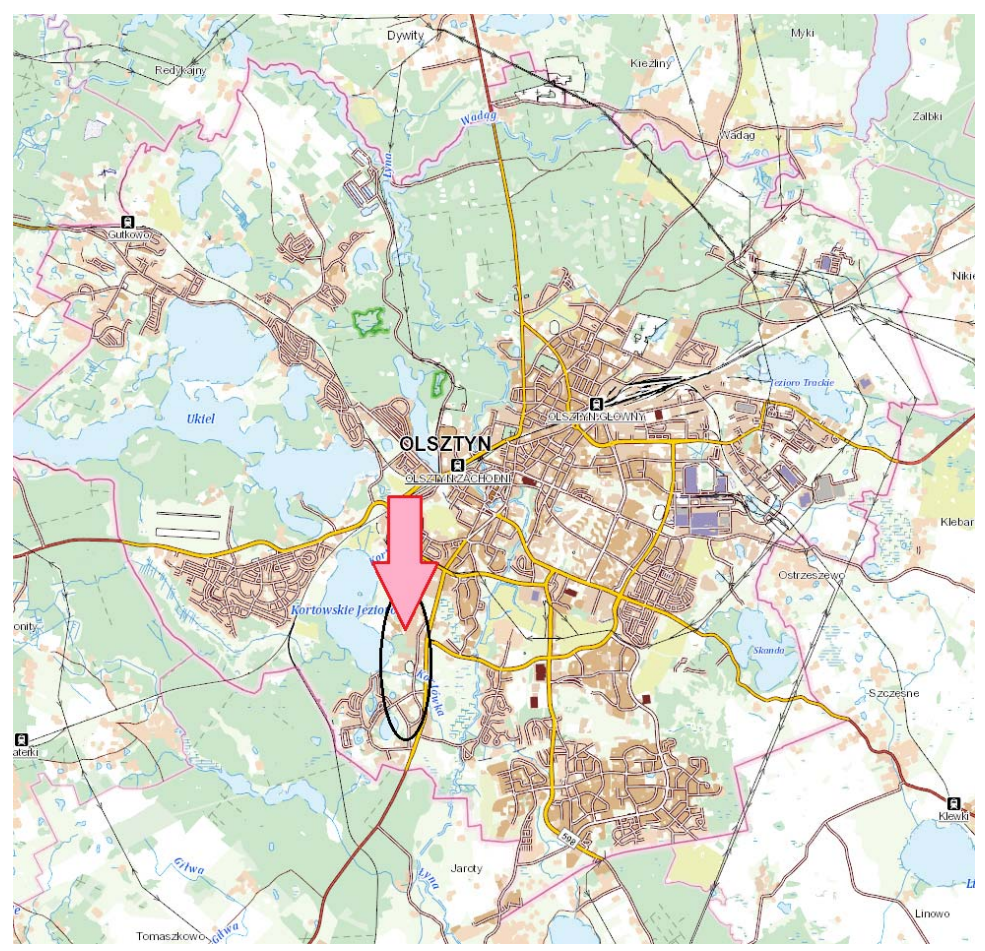

Fig. 1. Location of University of Warmia and Mazury buildings and facilities in the city of Olsztyn. Source: own elaboration with the use of the map available through Geoportal (http:/

/www.geoportal.gov.pl, retrieved 20.04.2018).

The own research was carried out in 2018 with a survey method. The survey questionnaire was distributed in person among 400 randomly chosen students of the University of Warmia and Mazury in Olsztyn. The university provides higher education to over 20,000 students (in the academic year $2016 / 2017$ - 21,058 students ) and this is the size of the general population of students. The selected sample can be said to be representative under standard assumptions (non-conformity level 0.5, level of confidence $95 \%$ and maximum error $5 \%$ ). The age structure of the sample reflects that, of the whole population, - the smallest percentage $(13 \%)$ were first-year students, while the largest number of respondents were in the age range between 20 and 25 years (84.5\%). Other participants declared being over $25(2.5 \%)$. Such an age structure warrants the use of the phrase "emergent adults" with reference to the respondents. However, due to the spatial concentration of the university buildings inside the campus, which is located in the south-western part of Olsztyn (Fig. 1), the question of what faculty the students study at was deliberately omitted.

\section{Empirical results}

Students make up a multi-million group of people, among whom there are equally numerous specific buyers in the property market, particularly in the residential rental market. Easthope and Gabriel (2008) observe that moving out of home to take up studies means the disclosure of a new identity, socalled "being between homes." This is when a complex relation emerges between the newly-acquired mobility and the attachment to the place called home. Over time, the change of residence begins to be identified with a new start and a new phase of a young person's identity (HOLTON 2015). Until quite recently, that intermediate stage of "between homes" meant living in university campus dormitories. As noted by BAJERSKI (2015), most of the students in Great Britain lived on campus, but later sought residence in or near the city centre. From ALLINSON'S research (2006), it appears that the most 
important factor for British students used to be the distance from the college; now, however, they have begun to give priority to the distance to the city centre. Another important determinant of the choice of residence was the perceived "studentiness of particular areas" (SMITH, HOLT 2004). In research on students in New Zealand, a different pattern was found, especially in students who came there from Asian countries. Such students explicitly favoured apartments located in the city centre, which followed from them being used to the noise and the direct access to food and entertainment services (STROOMBERGEN 2003). One more pattern was found - students from Asia often started by renting a flat with New Zealand families, and then moved to apartments rented and shared with other students. They explained that they wanted more independence and quoted wide cultural differences, e.g. concerning the preparation of meals (COLLINS 2010).

The presence of students in the residential rental market is also observed in Poland, where 1,348,822 people attended tertiary institutions in the academic year 2016/2017 (Szkolnictwo ...2017). The largest number of students attended college or university in the Masovian Voivodeship (19\%) followed by Lesser Poland (125). Per 10,000 inhabitants, the largest numbers of students attending tertiary institutions were in Masovia, Lesser Poland, Lower Silesia and Pomerania (from 503 to 401 people, GUS data). The tendency to conclude rental agreements in the private market is confirmed by empirical research; for example, the data for Szczecin suggests that as many as $67 \%$ of students who had moved to the city lived in private accommodation, with the others residing in dormitories (SKOTARCZAK, NOWAK 2010). At the national level, the majority of apartments rented by students were shared with peers - students chose renting spare rooms in family homes less and less frequently, quoting the difficulty in living alongside people from a different generation and sharing the bathroom and kitchen ${ }^{4}$. On the other hand, the dormitories have a disadvantage of being closed to visitors at certain regulated times ${ }^{5}$. At the same time, the studies of the Polish rental market show an increase in the market share of the people under the age of 30 and a rapid decrease in the older groups (among 30-49-year-olds, the percentage of persons living in mortgaged apartments was relatively high). The rented apartments (the free market rent) were mostly occupied by unmarried persons of relatively low income, living in the largest cities of Poland. The average time of occupation was rather short - below 5 years (RUBASZEK, CZERNIK 2016).

In the case of Olsztyn (Fig. 2), $67 \%$ of the students concluded a rental agreement for a flat or room in the private market. The largest group (nearly $40 \%$ ) lived in a rented apartment, most of them with peers. The second largest group were students who occupied a room in a family home occupied by the owners $(27.5 \%)$, followed by those living in dormitories $(14.8 \%)$. The remaining students lived at their parents' or relatives,' or owned their own apartment.

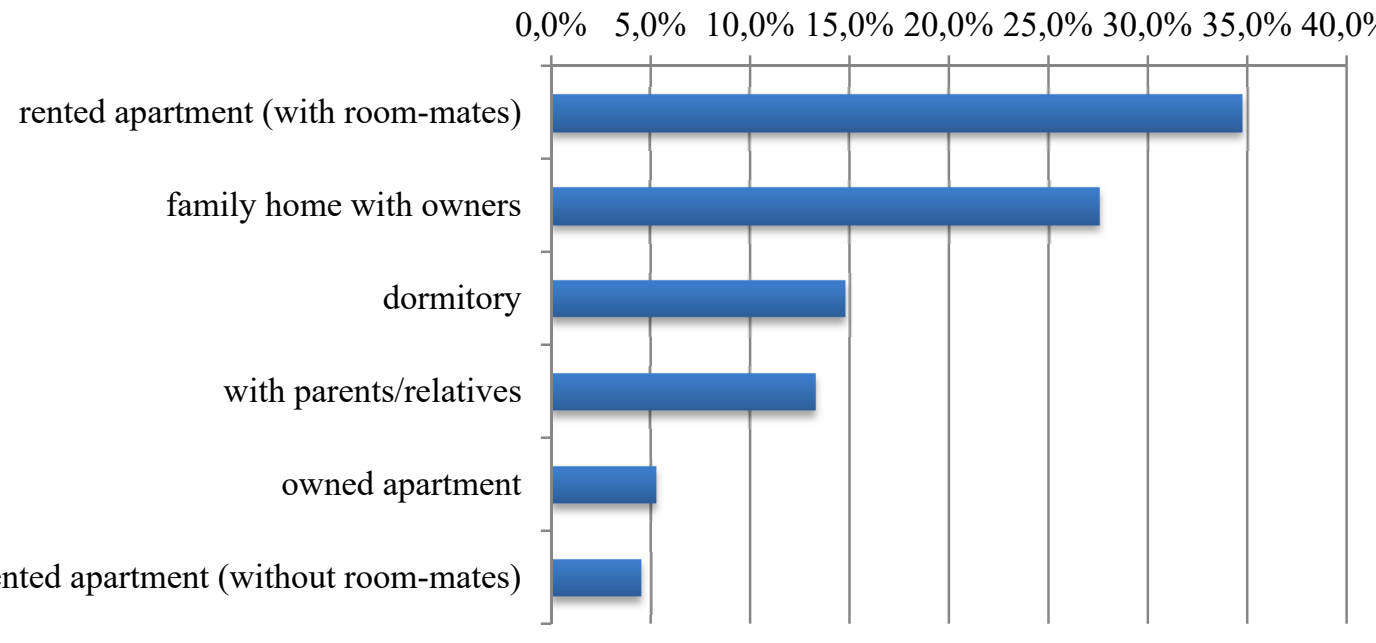

Fig. 2. Type of property occupied by the UWM students in the academic year 2017/2018. Source: own elaboration based on survey results.

\footnotetext{
4 Pokój dla student coraz droższy (http:/ / serwisy.gazetaprawna.pl, retrieved 10.04.2018).

5 Lokal dla studenta: Akademik, stancja czy mieszkanie? Sprawdź ceny w poszczególnych miastach (http:/ / serwisy.gazetaprawna.pl, retrieved 10.04.2018).
} 
The percentage of persons renting an apartment increased along with the age of the respondents (37\% for persons below 20 years of age and $40 \%$ at the age of 20-25), and then gave way to persons owning their own apartments ( $20 \%$ of students over the age of 25 still rented accommodation, while $30 \%$ already owned an apartment). In contrast to the New Zealand students, the percentage of people renting a room in a family home did not decrease with the age of respondents; on the other hand, the share of people living at their parents' or relatives' homes dropped noticeably - in the first age cohort, it was $31 \%, 11 \%$ in the second, and zero in the third.

Among the persons renting an apartment (both with flatmates or on their own), an overwhelming majority (93\%) lived in multi-family buildings (blocks), in both old $(53 \%)$ and new $(47 \%)$ housing. The reasons can be found both on the supply side (the majority of city apartments offered for rent are found in such buildings) and the demand side - 73\% of the respondents indicated the largest of Olsztyn's "bedroom estates" as the optimal location.

The students were also asked about the factors that determined their choice of a particular residence during the studies (Fig. 3). For nearly all of the respondents, the key determinants were the location and price. Half of the group highly valued the standard and the transport accessibility while a quarter of the respondents mentioned the size of the apartment and the absence of the owner.

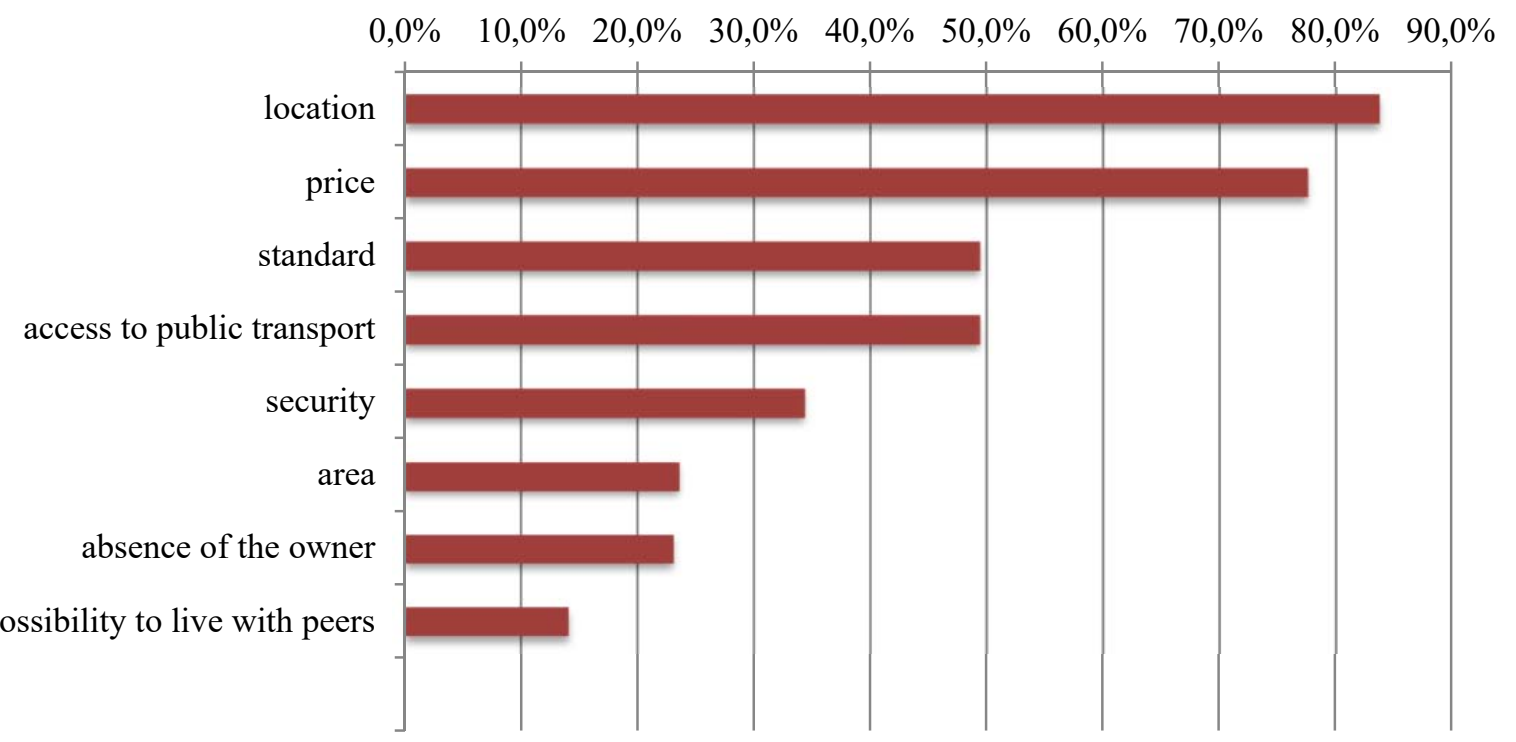

Fig. 3. Most important features of dwellings when choosing the place of residence. Source: own elaboration based on survey results.

The meaning of the term "location" was further studied through an analysis of the importance of facilities which, according to the respondents, should be in the vicinity of what students describe as an attractive location (Fig. 4). As for the Olsztyn students, the essential features were shops (82\%) and bus or tram stops $(68 \%)$. The presence of these facilities was more important than the distance to the university (54\% of the answers), recreational facilities, health centres or coffee shops. No student mentioned other objects.

The second most important determinant for the rented property was its price ${ }^{6}$. Students who lived in a dormitory paid rent according to the rates set by the foundations which manage the dormitory. The prices ranged from PLN 315/month for a place in a 3-person room, with a shared bathroom in the hall to PLN450 /month for a single-person room7. For apartments rented in the private market, the monthly rent usually ranged from PLN 500 to $700(48 \%)$ or between PLN 300 and $500(40 \%)$. In exceptional cases, the tenants paid more than PLN $700(9 \%)$ or less than PLN 300 (3\%). The charges varied depending on the presence of the owners in the apartment (Fig.5). More than a half of the

\footnotetext{
6 The analysis does not cover persons living at their parents' or relatives' homes, as these are non-market arrangements.

${ }^{7}$ www.zak.olsztyn.pl (retrieved 24.04.2018).
} 
respondents who shared a house with the owner paid rent in the range of PLN 300-500, while the tenants in apartments where the owner was absent usually paid PLN 500-700 per month.

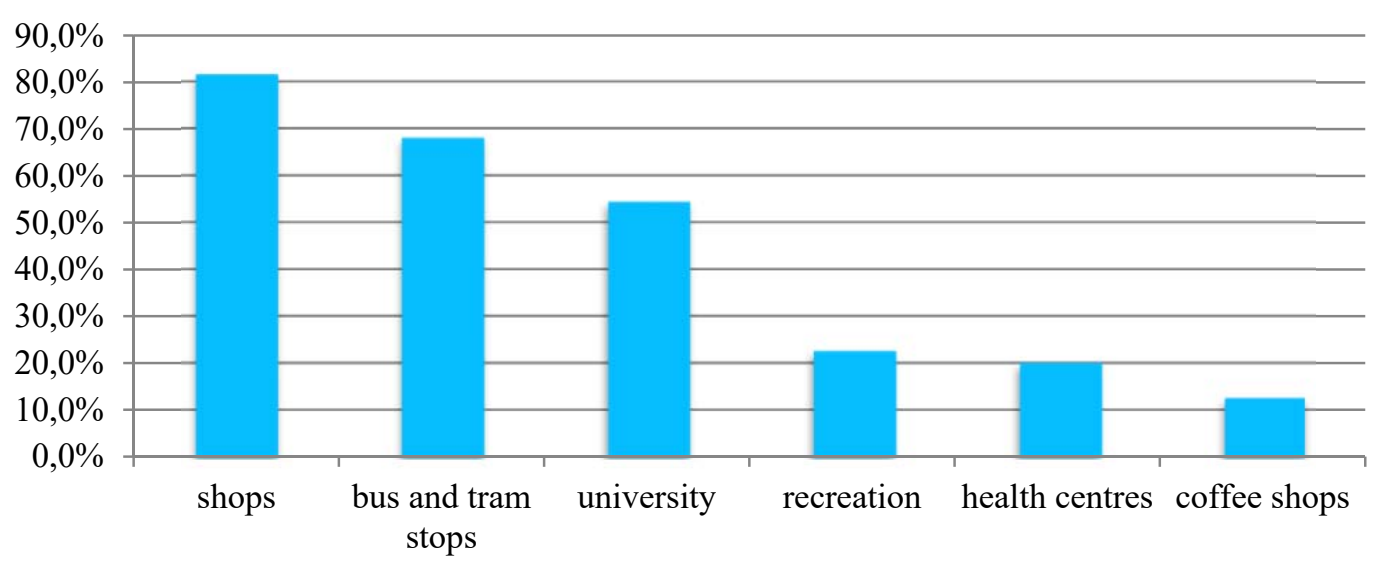

Fig 4. The most important facilities the vicinity of which makes a location attractive. Source: own elaboration based on survey results.

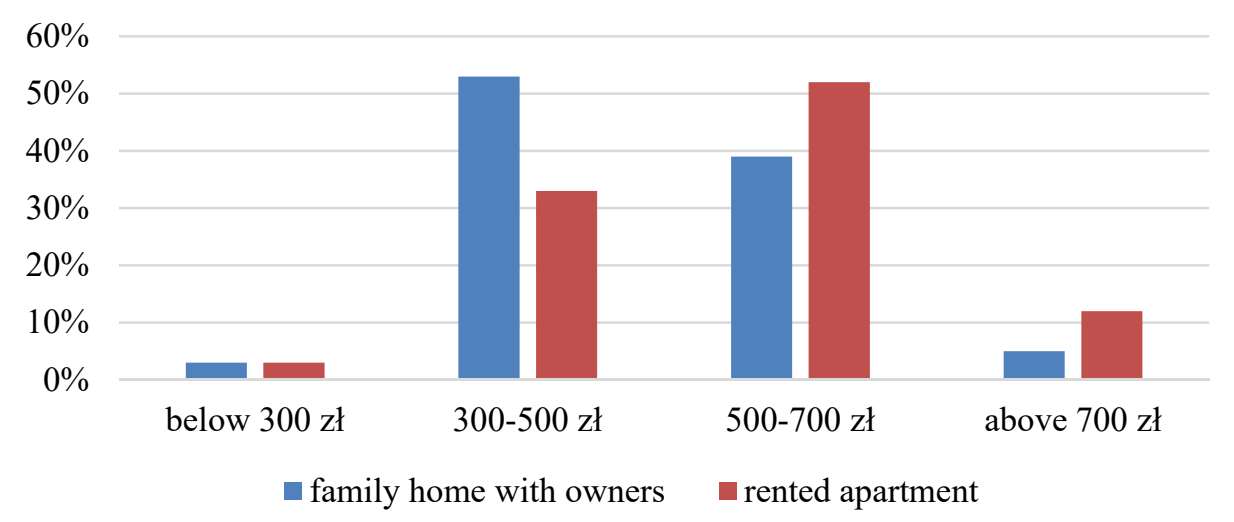

Fig. 5. Rates of residential rent in the private market (one place/month). Source: own elaboration based on survey results.

The rate of the rent did not depend on the type of the building, but went up with the demand for a particular location and the absence of the owner in the property. The areas of Olsztyn most frequently sought by the students turned out to be:

- the "bedroom neighbourhoods" far from campus (60 minutes on foot or 20-25 minutes by bus), but well-connected by public transport, lying along Wilczyńskiego Road (Generałów Estate, Jaroty, Pieczewo $-30 \%$ of the respondents),

- Podgrodzie Estate in the vicinity of the university (25 minutes on foot or 10 minutes by bus) $26 \%$,

- estates in close vicinity of the university - Słoneczny Brzeg and Brzeziny (19\%).

In the first two locations, most of the apartments on offer (with the owner absent) were flats, with most students paying over PLN 500 per month. In the estates closer to the university the students were mostly offered boarding houses living alongside owners, thus the rent was in the range of PLN 300-500.

It is worth looking at the set of factors determining the demand for a particular location. For most neighbourhoods, their attractiveness followed from their proximity to the university, so far-out estates like Dajtki or Zatorze were to be found less attractive. However, what transpires from the own research, is that for the students of Olsztyn, the distance from the university was not the only demand determinant and was offset by other advantages of the location. This is best exemplified by the greatest popularity of the Generałów Estate, Jaroty and Pieczewo (GJP), in contrast to the closer and better connected (direct bus and tram connection) Nagórki estate, chosen by merely $7 \%$ of the students renting an apartment in the range of PLN 300-500/month. To study this further, the respondents were 
asked about their subjective feelings towards the particular neighbourhoods and the reason behind them. The respondents indicated that these two estates seemed to be optimal locations during their studies. A large majority (61\%) identified the GJP estates, followed by Podgrodzie and the close neighbourhood of the campus ( $41 \%$ each). The students expressed the following opinions to justify their answers: "Everything can be found here - it's a city within a city," "most residents are young people," "this estate keeps growing - new blocks are being built, with service points and shops inside them" and "cool atmosphere - modern buildings, young people, it is safe." On the other hand, the following factors decided against a location: "bad reputation" of the neighbourhood (the image of a dangerous place, "you can get stabbed here"), lack of good communication ("massive traffic jams," "far from everywhere") and the age structure of the residents and buildings ("old estates, young people tend to avoid them").

Students can still be active in the local property market upon the completion of their education. The graduates may stay in the university city and keep renting apartments or purchase their own. However, in the analysed group, this was not a significant factor - as many as $87 \%$ of the respondents declared that they were not planning to stay in Olsztyn nor buy an apartment in the city. This lack of identity with the city is further confirmed by the fact that only $16 \%$ of the survey participants complied with the obligation to register for residence in Olsztyn. At the same time, the failure to register means that $84 \%$ of the students (which can be estimated to be nearly 18,000 people, equivalent to $10 \%$ of the total population of Olsztyn) live in the city, but are not covered in official statistics.

\section{Conclusions}

Every year, when a new academic year is about to begin, over a million students in Poland conclude residential rental agreements, a significant number of which are in the private market. Students are less and less willing to live in dormitories or rent rooms in family homes occupied by the owner; they have an increasing tendency to rent whole apartments which they share with flatmates.

As present research suggests, students, who represent the age group of the so-called "emerging adults," demonstrate preferences for a rental apartment which are specific to their age group. The most popular apartments among the students satisfy the following conditions:

- guarantee independence and freedom (no reception desk, no owner, and no strict regulations)

- are part of a multi-family house (blocks of flats),

- are in the neighbourhoods which are well-connected with the university, but also with modern buildings and shops,

- are in the areas which experience the process of "studentification" - they are inhabited mostly by young people and other students, which provides for the "studenty" atmosphere of the place and the sense of security.

The presence of these values can offset higher rents and a greater distance to the university. At the same time, it must be stressed that, along with the growing affluence of the Polish society (the parents of students enjoy a growing stable income), students expect a higher standard of the rented properties - the standard was the third most important factor. What can then be observed are both the increasing "studentification" of the new urban estates with the dominance of multi-family housing and the more evident presence of student tenants in relatively expensive locations.

\section{References}

Adams D., Leishman C., MoORE C., 2009, Why not Build Faster? Explaining the Reluctance of UK Housebuilders to Speed up Supply of New Homes for Owner Occupation, Town Planning Review, No. 80, pp. 291-314

ALLINSON J., 2006, Over-educated, over-exuberant, and over there? The Impact of Students on Cities Planning, Practice and Research, No. 21, pp. 79-94

ANDREWS D., CALDERA SÁNCHEZ A., 2011, Drivers of Homeownership Rates in Selected OECD Countries, OECD Economics Department Working Papers, No. 849.

ARNETT J.J., 2000, Emerging Adulthood A Theory of Development From the Late Teens through the Twenties, American Psychologist, Vol. 55., No. 5, pp. 469-480

August M., WAlKs A., 2018, Gentrification, Suburban Decline, and the Financialization of Multi-family Rental Housing: The Case of Toronto, Geoforum 89, pp. 124-136 
BAJERSKI A., 2015, Student jako użytkownik miasta: brytyjskie doświadczenia studentyfikacji (Student as the City User: British Experience in Studentification), Rozwój Regionalny i Polityka Regionalna, No. 31, pp. 47-56

BRZEZICKA J., WiśNIEWSKI R., 2014, Price Bubble in the Real Estate Market - Behavioral Aspects, Real Estate Management and Valuation, Vol. 22, No. 1, pp. 80-93

Cennik domów studenckich (Price-list of Student Houses), www.zak.olsztyn.pl, accessed 24.04.2018

CHEN J., M. JIN., 2014, Income elasticity of housing demand in China: Micro-data evidence from Shanghai, Journal of Contemporary China, 23 (85), pp. 68-84

ColliNS F.L., 2010, International Students as Urban Agents: International Education and Urban Transformation in Auckland, New Zealand, Geoforum, No. 41, pp. 940-950

Cuerpo C., Kalantaryan S., PONTUCH P., 2014, Rental Market Regulation in the European Union, European Economy, No. 515, http:/ / ec.europa.eu, accessed 25.04.2018

CZERNIAK A., RUBASZEK M., 2016, Znaczenie prywatnego rynku najmu nieruchomości dla stabilności makroekonomicznej krajów strefy euro (The Importance of Private Real Estate Rental Market for Macroeconomical Stability of Euro Zone), Materiały i Studia (Studies and Materials), No. 325, Narodowy Bank Polski (National Bank of Poland).

Dane statystyczne dotyczące ksztatcenia wyższego (Statistical Data Concerning Higher Education) http:/ / ec.europa.eu, accessed 25.04.2018

DE BOeR R., BitetTi R., 2014, A Revival of the Private Rental Sector of the Housing Market?: Lessons from Germany, Finland, the Czech Republic and the Netherlands, OECD Economics Department Working Papers, No.1170.

DE PALMA A., MOTAMEDI K., PICARD N., WADDELL P., 2005, A Model of Residential Location Choice with Endogenous Housing Prices and Traffic for the Paris Region, European Transport \Trasporti Europei Vol. 31.

EASTHOPE H., GABRIEL M., 2008, Turbulent Lives: Exploring the Cultural Meaning of Regional Youth Migration, Geogr. Res., No. 46 (2), pp. 172-182

Friedman M., 1957, The Permanent Income Hypothesis. A Theory of the Consumption Function, Princeton University Press

GILBERT A., 2016, Rental Housing: The International Experience, Habitat International, Volume 54, Part 3 , May 2016, pp. 173-181

Grover R., Munro-Faure P., Soloviev M., 2002, Housing Tenure Change in the Transitional Economies, [in:] PAYNE G. (Ed.), Land, Rights \& Innovation - Improving Tenure Security for the Urban Poor, ITDG (2002), pp. 41-56

HALL P., 1997, The University and the City, GeoJournal, 41, pp. 301-309

Holton M., 2015, Adapting Relationships with Place: Investigating the Evolving Place Attachment and 'Sense of Place' of UK Higher Education Students During a Period of Intense Transition, Geoforum 59, pp. 21-29

HUlSE K., REYNOLDS M., YATES, J., 2014, Changes in the Supply of Affordable Housing in the Private Rental Sector for Lower Income Households, 2006-11, AHURI Final Report No. 235, Australian Housing and Urban Research Institute Limited, Melbourne.

JADACH-SEPIOŁO A., 2014., Analiza polskiego rynku nieruchomości ze szczególnym uwzględnieniem nieruchomości przeznaczonych lub wykorzystywanych na cele mieszkaniowe za lata 2012-2014 z prognoza na rok 2015 (Polish Real Estate Market Analysis with Special Attenton Paid on Real Estate Destined for or Used as Housing Real Estate in 2012-2014 with Forecast for 2015), Instytut Rozwoju Miast, Kraków

KUCHARSKA-STASIAK E., 2016, Ekonomiczny wymiar nieruchomości (Economic Dimension of Real Estate), PWN, Warszawa

KuCHARSKA-STASIAK E., 2016, Grey Zone in the Real Estate Market, Real Estate Management and Valuation, vol. 24, No. 3, pp. 83-92

KURZ K., 2004, Homeownership and social inequality in West Germany, [in:] K. Kurz and H. P. Blossfeld (Eds) Homeownership and Social Inequality in Comparative Perspective, ch. 2. Stanford, CA, Stanford University Press

LEE T.H., 1968, Housing and Permanent Income: Tests Based on a Three-year Reinterview Survey, The Review of Economics and Statistics, pp. 480-490

Lokal dla studenta: Akademik, stancja czy mieszkanie? Sprawdź ceny w poszczególnych miastach (Apartment for a Student: Student House, Apartment with Family or Independent One?), http:/ / serwisy.gazetaprawna.pl, accessed 10.04.2018 
MCFADDEN D., 1997, Modelling the Choice of Residential Location, [in:] Quigley J. (ed.) The Economics of Housing, Edwarg Elgar, London.

NYKIEL L., 2012, Mieszkania na wynajem jako warunek rozwoju rynku mieszkaniowego (Apartment for Rent as a Condition for Residential Market Development), Studia i Materiały Towarzystwa Naukowego Nieruchomości (Studies and Materials of the Polish Real Estate Scientific Society), Vol. 20, No. 3, pp. 95-110

Pokój dla studenta coraz droższy (Apartment for a Student is Becoming more Expensive), http:/ / serwisy.gazetaprawna.pl, accessed 10.04.2018

Russo A.P., TATJER L.C., 2007, From Citadels of Education to Cartier Latins (and Back?): the Changing Landscapes of Student Populations in European Cities, Geography Compass, Vol. 1 (5), pp. 1160-1189

SKOTARCZAK T., NOWAK M.J., 2010, Preferencje mieszkaniowe kandydatów na studia oraz studentów pierwszego roku Akademii Rolniczej w Szczecinie (Residential Preferences of Students and Candidates in Agricultural Academy in Szczecin), Folia Pomer. Univ. Technol. Stetin., Oeconomica 277 (58), pp. 7180

SKWIROWSKI P. Wynajem mieszkań 2016. Musisz wybrać formę opodatkowania (Flats for Rent in 2016. You have to Choose the Tax Form), http:/ / wyborcza.biz, accessed 10.04.2018

SMITH D., 2009, Guest editorial: student geographies, Environment and Planning A, 41 (8), pp. 1795-1804

SMith D.P., Holt L., 2004, Processes and Patterns of Studentification in Brighton and Eastbourne: A Report to the Vice Chancellors Office, University of Brighton, Brighton

Sprawozdanie na temat strategii Komisji Europejskiej pt. „Europejskie szkodnictwo wyższe na świecie” (Report on European Commission Strategy "European Higher Education Worldwide"), www.senat.gov.pl, accessed 25.04.2018

StROOMBERGEN A., 2003, International Students: their Impact on Auckland City, Infometrics for Auckland City Council, Auckland.

Szkolnictwo wyższe w roku akademickim 2016/2017 dane wstępne (Higher Education in Academic Year 2016/2017, Preliminary Data), http:/ / stat.gov.pl, accessed 20.04.2018

TROJANEK M., 2013, Customer Behaviour Patterns on the Primary Housing Market in Poznan in the Period 2010-2011, Real Estate Management and Valuation, Vol. 21, No. 4, pp. 47-53

VeNTI S. F., WISE D. A., 2004, Aging and Housing Equity: Another Look, [in:] D. A. Wise (Ed.) Perspectives on the Economics of Aging, Chicago, IL: The University of Chicago Press, pp. 127-175

Warunki życia rodzin w Polsce. 2014 (Polish Families' Living Conditions. 2014), (http://stat.gov.pl, dostęp 20.04.2018)

Watson D., WebB R., 2009, Do Europeans View their Homes as Castles? Homeownership and Poverty, Urban Studies, 46 (2009), pp. 1787-1805

ŹRÓBEK-RÓŻAŃSKA A., ZYSK E., ŹRÓBEK-SOKOLNIK A., 2016, Studies over Characteristics Shaping Residential Attractiveness of Suburban Rural Areas, Acta Scientiarum Polonorum. Oeconomia, 15 (3), pp. 145-154. 